PNNL- 21865

U.S. DEPARTMENT OF

(2) ENERGY

Prepared for the U.S. Department of Energy

under Contract DE-AC05-76RL01830

\title{
Tethys and Annex IV Progress Report for FY2012
}

\author{
L Hanna \\ S Butner \\ J Whiting \\ A Copping
}

September 2012

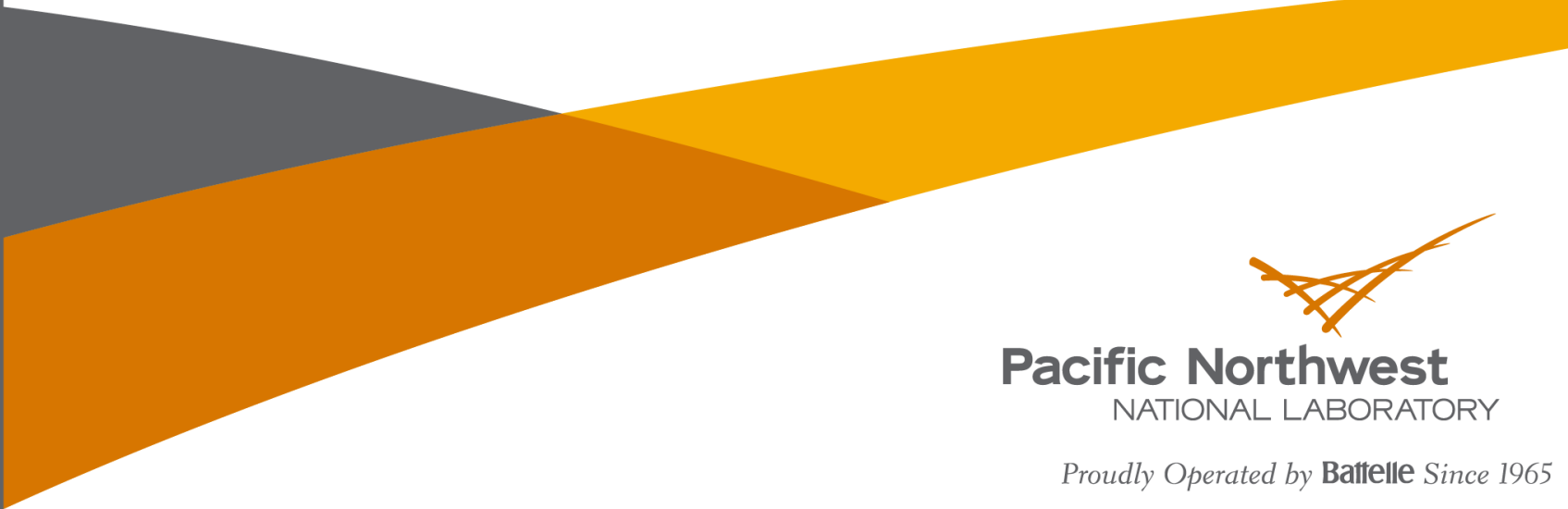




\title{
DISCLAIMER
}

This report was prepared as an account of work sponsored by an agency of the United States Government. Neither the United States Government nor any agency thereof, nor Battelle Memorial Institute, nor any of their employees, makes any warranty, express or implied, or assumes any legal liability or responsibility for the accuracy, completeness, or usefulness of any information, apparatus, product, or process disclosed, or represents that its use would not infringe privately owned rights. Reference herein to any specific commercial product, process, or service by trade name, trademark, manufacturer, or otherwise does not necessarily constitute or imply its endorsement, recommendation, or favoring by the United States Government or any agency thereof, or Battelle Memorial Institute. The views and opinions of authors expressed herein do not necessarily state or reflect those of the United States Government or any agency thereof.

\author{
PACIFIC NORTHWEST NATIONAL LABORATORY \\ operated by \\ BATTELLE \\ for the \\ UNITED STATES DEPARTMENT OF ENERGY \\ under Contract DE-AC05-76RL01830
}

Printed in the United States of America

Available to DOE and DOE contractors from the

Office of Scientific and Technical Information,

P.O. Box 62, Oak Ridge, TN 37831-0062;

ph: (865) 576-8401

fax: $(865) 576-5728$

email: reports@adonis.osti.gov

\author{
Available to the public from the National Technical Information Service, \\ U.S. Department of Commerce, 5285 Port Roy al Rd., Springfield, VA 22161 \\ ph: (800) 553-6847 \\ fax: $(703) 605-6900$ \\ email: orders@ntis.fedworld.gov \\ online ordering: http://www.ntis.gov/ordering.htm
}




\title{
Tethys and Annex IV Progress Report for FY 2012
}

\author{
L Hanna \\ S Butner \\ J Whiting \\ A Copping
}

September 2012

Prepared for

the U.S. Department of Energy

under Contract DE-AC05-76RL01830

Pacific Northwest National Laboratory

Richland, Washington 99352 
PNNL-21865

\section{Summary}

As the offshore renewable energy industry progresses in U.S. and international waters, the demand for data and information on how marine and hydrokinetic (MHK) technologies may interact with the marine environment has begun to increase. Data and information on the environmental effects of offshore renewable energy developments are limited, and many of the publicly accessible resources are scattered across various scientific journals and technical reports from many different countries. To help organize and disseminate this information and data to researchers, project developers, regulators, and the MHK community, the U.S Department of Energy's (DOE) Wind and Water Power Technologies Office (WWPTO) has directed Pacific Northwest National Laboratory's web developers and marine scientists to create the Tethys and Annex IV knowledge bases.

Tethys is a web-based knowledge management system with semantic properties to enable enhanced searching and tagging capabilities and provides researchers, project developers, and regulators with access to information and data pertaining to the environmental effects of offshore renewable energy. Tethys also facilitates connectivity and collaboration amongst the offshore renewable energy community by providing a means for communicating and disseminating important information and data on stressor/receptor interactions between MHK devices and the marine environment. As this site continues to grow in content, additional efforts and resources will be focused on creating a commons for Tethys to facilitate more communication and awareness from the MHK community and further enhance the sites functionalities in order to continue fostering a clear dissemination channel for information and research among MHK researcher, project developers and regulators.

Annex IV, led by the U.S. and DOE, is an international collaborative project amongst member nations of the Ocean Energy Systems (OES). The Annex IV knowledge base is housed within Tethys, and primarily consists of metadata collected from a wide range of international ocean energy developments and research projects focused on the environmental effects of ocean energy.

As the Tethys and Annex IV knowledge bases continue to grow and more information and data are disseminated across the MHK community, the uncertainty about the environmental effects of MHK development will begin to be reduced and the efficiency and predictability of the overall permitting process for MHK projects will be increased. Additionally, as the MHK community begins to grow and utilize Tethys as a tool to facilitate communication and collaboration, it will begin to simplify the permitting and siting process for MHK developments, thus becoming an invaluable tool for project developers, researchers, regulators and the MHK community as a whole. 


\section{Contents}

1.0 Introduction and Purpose 1

2. Highlights for FY12 2

2.1 Site Development 2

2.2 Data Curation and Partnerships $\quad 3$

2.3 Site Maintenance and Management 3

$2.4 \quad$ Related Projects - Annex IV $\quad 5$

3 Outreach $\quad 6$

\section{Tables}

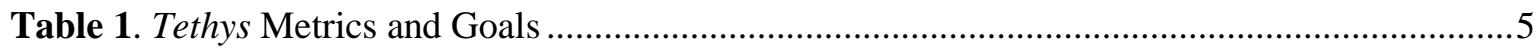


PNNL-21865

\subsection{Introduction and Purpose}

The marine and hydrokinetic (MHK) environmental Impacts Knowledge Management System, dubbed "Tethys" after the mythical Greek titaness of the seas, is being developed by the Pacific Northwest National Laboratory (PNNL) to support the U.S. Department of Energy's Wind and Water Power Program (WWPP). Functioning as a smart database, Tethys enables its users to identify key words or terms to help gather, organize and make available information and data pertaining to the environmental effects of MHK and offshore wind (OSW) energy development. By providing and categorizing relevant publications within a simple and searchable database, Tethys acts as a dissemination channel for information and data which can be utilized by regulators, project developers and researchers to minimize the environmental risks associated with offshore renewable energy developments and attempt to streamline the permitting process.

Tethys also houses a separate content-related Annex IV data base with identical functionality to the Tethys knowledge base. Annex IV is a collaborative project among member nations of the International Energy Agency (IEA) Ocean Energy Systems - Implementing Agreement (OES-IA) that examines the environmental effects of ocean energy devices and projects. The U.S. Department of Energy leads the Annex IV working with federal partners such as the Federal Energy Regulatory Commission (FERC), the Bureau of Ocean Energy Management (BOEM), and the National Oceanic Atmospheric Administration (NOAA). While the Annex IV database contains technical reports and journal articles, it is primarily focused on the collection of project site and research study metadata forms (completed by MHK researchers and developers around the world, and collected by PNNL) which provide information on environmental studies and the current progress of the various international MHK developments in the Annex IV member nations.

The purpose of this report is to provide a summary of the content, accessibility and functionality enhancements made to the Annex IV and Tethys knowledge bases in FY12. 
PNNL-21865

\section{Highlights for FY12}

The primary objective for FY12 was to enhance the reliability and accessibility of the Tethys knowledge base, and to continue expanding the knowledge base through the curated addition of documents, datasets, modeling scenarios, and other information types pertaining to the environmental effects of offshore renewable energy. Metrics and associated goals were also created as a part of an overall measurement plan for Tethys, enabling PNNL researchers and Tethys users to evaluate the site's effectiveness and its overall usability.

\subsection{Site Development}

Site development focuses on creating and extending the Tethys technical infrastructure to ensure that the required functionality is working effectively and that new features are added in a timely and cost-effective manner. Site development was a major focus of the Tethys task in FY12. Highlights include:

- The MHK and OSW databases were combined into one comprehensive knowledge base. The MHK and OSW databases had been separate knowledge bases containing their own information. Merger of the data is expected to promote sharing of information between stakeholders for these two renewable energy types and to enhance the searchability of Tethys.

- Several improvements were made to enhance the user experience and increase the scalability of Tethys as data collection grows. Improved handling of search results and a new indexing program were implemented with the net result of significantly decreasing the page-loading times for the Tethys and Annex IV knowledge bases.

- The Tethys map viewer was changed in order to allow association of any type of document or report with a specific location or project site. Originally, site associations were limited primarily to the MHK projects extracted from the FERC docket.

- The knowledge base was reorganized to streamline data entries and maintain uniformity amongst all media types. This enabled properties such as the Technology Type to be a label across many different media types, thus enhancing the search capabilities of the site.

- "Support" pages such as a Tethys blog, FAQs, contacts, recent news, and definition pages for stressors, receptors, and technology types were created and an explanation of Tethys and Annex IV were added to educate and direct users to the appropriate information. 


\subsection{Data Curation and Partnerships}

Data curation, which includes properly vetting, classifying, abstracting and indexing documents, is a critical aspect of maintaining the Tethys knowledge base. Information housed in Tethys must be current and new research and information must be incorporated when available. Partnerships with external agencies and other stakeholders can be invaluable resources to review and attain content. Throughout FY 12, Tethys focused on the following data curation and partnership activities:

- The PNNL Tethys team, led by Luke Hanna and assisted by Pacific Energy Ventures (PEV) added approximately 400 new knowledge base entries between October 1, 2011 and September 1, 2012, greatly exceeding the goal of adding an average of 40 documents each quarter. As of September 1, 2012, Tethys contained approximately 600 entries in the Tethys knowledge base. Approximately 26 of those entries are associated with a specific geographic location and hence viewable via the Tethys map viewer.

- The Tethys team also generated original data via the Annex IV surveying effort, which allowed us to add 61 project site summaries and/or documents associated with sites, and 84 research study summaries. Scheduled for broader deployment in early CY2013, these documents are currently available to a small group of Annex IV participants, and represent a significant source of original information about MHK development activities throughout the world.

\subsection{Site Maintenance and Management}

To ensure the operational success of Tethys, and to address user's feedback regarding site functionality, website maintenance and management efforts must be an ongoing effort. In addition to improving the functionality of Tethys where opportunities present themselves, insuring that the site is kept current with security and software code updates requires continual monitoring by the Tethys team. The Tethys team has implemented an issue tracking system that allows client and user community requests, as well as system upgrade tasks, to be tracked and assigned to individuals within the team.

Key FY12 maintenance and management activities included:

- To assess the functionality, content, and practicality of Tethys to other professionals in offshore renewable energy community, several researchers in the offshore renewable energy community were asked to peer review the Tethys knowledge base. Comments and suggestions from the review were taken into consideration and Tethys was amended to better suit their issues and concerns.

- Tethys Web Metrics and Goals (Table 1) were prepared and approved by WWPP and delineates the key performance metrics and a reporting process for using them to monitor and improve the performance of Tethys. By identifying these website performance metrics, several quarterly and annual goals are also described to ensure that Tethys continues to grow in an efficient and sustainable manner. Unfortunately, our ability to collect web metrics was compromised during the final quarter of FY12 due to technical issues stemming from PNNL's web security system. While these issues have been resolved moving forward into FY13, our FY12 data primarily 
reveals our overall traffic, and top rated documents/features. The data should be considered provisional, and will be updated in Q1 FY13 following our first quarter of fully responsive data.

- Highlights of the FY12 web site data include:

○ From June 20 - Sept 19, 2012 Tethys averaged 19,485 hits per day. This figure includes internal (PNNL/DOE) users and search engine hits so should be taken as an optimistic estimate of site activity.

- A more reasonable estimate can be derived from looking at download activity on technical documents indexed in Tethys. These documents are rarely accessed by PNNL users for maintenance purposes, and accessed relatively infrequently by users who are not seeking the data they contain. From this data we find:

- The most downloaded document is the Fundy Ocean Research Center of Energy's Environmental Effects Monitoring report; downloaded more than 6,800 times (an average of more than 68 downloads per day over the observation period).

- 12 reports were downloaded 1,000 or more times during the observation period.

- More than 100 documents indexed in Tethys' knowledge base were downloaded 200 or more times during the 100 day observation period.

- Modifications were implemented to the generation of the use logs that allow much greater resolution of user patterns, including an analysis of average number of pages downloaded per user, distribution of countries from which downloads originate, and search terms that are being used to find Tethys documents. These data will be reflected in quarterly reporting from Tethys starting at the conclusion of Q1 FY13. 
Table 1. Tethys Metrics and Goals

\begin{tabular}{|c|c|c|}
\hline Metric & Goal & Explanation \\
\hline Total user sessions & $\begin{array}{c}10 \% \text { increase on annual basis, } \\
\text { based on first year of operation, to } \\
\text { be tracked on revolving quarterly } \\
\text { basis. }\end{array}$ & $\begin{array}{l}\text { Activity measure that needs to be } \\
\text { tracked as a measure of success. }\end{array}$ \\
\hline Total page impressions & $\begin{array}{c}10 \% \text { increase on annual basis, } \\
\text { based on first year of operation, to } \\
\text { be tracked on revolving quarterly } \\
\text { basis. }\end{array}$ & $\begin{array}{l}\text { Activity measure that needs to be } \\
\text { tracked as a measure of success. }\end{array}$ \\
\hline $\begin{array}{c}\text { Average page impressions per } \\
\text { user session }\end{array}$ & $\begin{array}{c}\text { Based on previously measured } \\
\text { metrics. }\end{array}$ & $\begin{array}{l}\text { Activity measure that needs to be } \\
\text { tracked as a measure of success. }\end{array}$ \\
\hline Number of documents indexed & $\begin{array}{l}\text { Increase by } 40 \text { documents per } \\
\text { quarter, through FY12-FY13 }\end{array}$ & \\
\hline $\begin{array}{c}\text { Number of websites linked from } \\
\text { Tethys }\end{array}$ & $\begin{array}{c}\text { Increase by } 10 \text { links to external } \\
\text { websites per quarter, through } \\
\text { FY12-FY13 }\end{array}$ & \\
\hline $\begin{array}{l}\text { Number of external websites } \\
\text { linked to Tethys }\end{array}$ & & $\begin{array}{l}\text { Can be increased through active } \\
\text { outreach, but beyond our control; } \\
\text { no numerical goal }\end{array}$ \\
\hline $\begin{array}{c}\text { Percentage of valid links in the } \\
\text { Tethys knowledge base }\end{array}$ & $\begin{array}{l}90 \% \text { of all links working at any } \\
\text { time }\end{array}$ & \\
\hline $\begin{array}{l}\text { Increased functionality and } \\
\text { usefulness of site }\end{array}$ & $\begin{array}{l}\text { Continued improvements } \\
\text { annually. }\end{array}$ & $\begin{array}{c}\text { Based on annual peer review by } 4 \\
\text { to } 6 \text { peer reviewers, using structured } \\
\text { questions. }\end{array}$ \\
\hline $\begin{array}{l}\text { Availability of information useful } \\
\text { to users }\end{array}$ & $\begin{array}{c}\text { Majority of site users are satisfied } \\
\text { with the information they retrieved } \\
\text { from Tethys }\end{array}$ & $\begin{array}{c}\text { Dialogue box to ask for feedback } \\
\text { or survey }\end{array}$ \\
\hline
\end{tabular}

\subsection{Related Projects - Annex IV}

During FY12, an Annex IV database and map view were added to Tethys to permit sharing of data collected under the aegis of the Annex IV collaborative project. This task, involving member nations of the International Energy Agency (IEA) Ocean Energy Systems (OES), examines the environmental effects of ocean energy devices and projects.

While the Annex IV database contains technical reports and journal articles, it is primarily focused on the collection of project site and research study metadata forms (completed by MHK researchers and developers around the world, and collected by PNNL, with assistance form the Wave Energy Center and the University of Plymouth) which provide information on environmental studies and the current progress of the various international MHK developments in the Annex IV member nations.

Annex IV data collections within Tethys are currently available to a small set of registered users representing each of the nations involved in the Annex. Current plans are to open the collection of data to the broader MHK community in early 2013. During FY12, much of the work completed in support of the 
Annex IV collection builds upon features that are already part of the Tethys knowledge base and is described in the preceding sections. Unique Annex IV activities in FY12 included:

- The Annex IV project site and research study metadata forms were finalized and are now available on the Tethys home page in a PDF format.

- The Annex IV map viewer was enhanced to display the associated location of each project site and research study metadata forms (assuming location information is available).

- Per the request of the Annex IV member nations, security provisions were enabled to restrict access to the Annex IV database to designated users such developers and researchers from member nations. The Annex IV knowledge base will be publicly available starting in early CY2013.

\section{Outreach}

The outreach component of a website such as Tethys is crucial in order to build the user community and educate the public on its purpose and functionality as a useful research tool. Outreach activities during FY 12 included:

- $\quad$ Global Marine Renewable Energy Conference (GMREC). The 2012 GMREC was held in Washington D.C. from April $24^{\text {th }}-26^{\text {th }}$. PNNL distributed Tethys bookmarks with the website's URL and a brief description of the site's purpose to attendees of GMREC. The WWPP also displayed a large monitor at their information booth to demonstrate the functionality and accessibility of the Tethys and Annex IV knowledge bases.

- $\quad$ Semantic Media Wiki Con 2012. This conference, aimed at developers using Semantic Media Wiki (the software platform on which Tethys is built) was held in Carlsbad, CA from April 25-27, 2012 and was attended by two Tethys development staff. Primary benefits from attending included networking with other users and developers of the technology; learning about and in some cases influencing the direction of future improvements to the software platform; and workshop sessions on how to conduct search engine optimization for wiki-based content, an important topic for improving the use statistics for Tethys. 


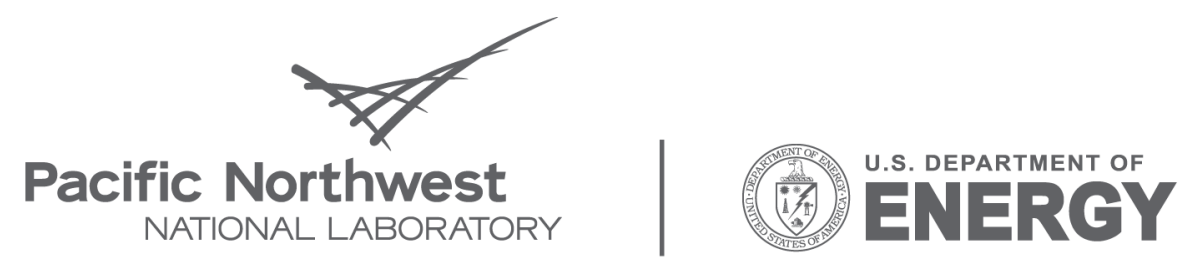

Proudly Operated by Battelle Since 1965

902 Battelle Boulevard

P.O. Box 999

Richland, WA 99352

1-888-375-PNNL (7665)

www.pnl.gov 